\title{
THE WAY FORWARD FOR EQUAL OPPORTUNITIES BY SEX IN EMPLOYMENT IN TURKEY AND BRITAIN
}

\author{
ÖZLEM ÖZKANLI - MUSTAFA F. ÖZBILGIN
}

\begin{abstract}
Based on a review of historical development of sex equality discourses, and practices in Turkey, and Britain, this paper identifies patterns, and trends of change, and explores how real change towards sex equality could be achieved in both countries. Three aspects of equal opportunities discourse, and practice were evaluated: legal framework, national machinery, and organisational approaches in both countries. It is argued that Turkish, and British women, despite the geographical, historical, economic, and cultural differences between their countries, share a common position as disadvantaged groups in employment. The statistical indicators of employment, and gender gap in pay, legislative provision, and the sociological studies of equality of opportunity in employment in both countries suggest that there is still ample opportunity for progress towards sex equality. However, the nature of proposed agendas of change in legislative, state policy, and organisational approaches to equality shows divergence between Turkey, and Britain.
\end{abstract}

\section{KEYWORDS}

Equal Opportunities; Gender; Women's Employment in Turkey and Britain; Comparative Employment Data. 
Studying development of sex equality in employment from a cross-national, and comparative perspective poses a challenge to ethnocentric understandings of gendered forms of employment discrimination, and promises a means to understand the effectiveness of strategies, and techniques which assume to promote sex equality. Studying Turkey and Britain in this context is very important as they represent the margins of the European cultural geography and sex equality practice, and comparative analysis of their experiences is educational for both practitioners and academics in the field.

This paper is organised in three sections: The practice, and discourse of sex equality in employment is explored in separate sections for each country. Comparisons, and conclusions are provided in the final section. Evaluation of discourse and practice in each country is performed by exploring effectiveness of legal framework, national machinery, and organisational approaches in Britain and Turkey. Identifying common and divergent patterns of sex equality, the paper offers insights into how real equality may be achieved in both countries. An outline of the issues raised in the paper are provided as an addendum to this paper.

\section{Sex Equality in Turkey}

The origins of the suffrage movement of Turkish women can be traced back to the declining years of the Ottoman Empire. Relaxation of the religious structure on sex segregation of public and private spheres of life during the period of national war of independence is considered an underlying reason behind the emergence of the suffrage movement in Turkey. Following the independence war, the early years of the modern day Turkish Republic witnessed significant legal changes in women's rights. Turkish women gained their political right to vote in local elections under the Law of Municipalities in 1930, and they won the right to vote in elections for, and to be elected to the Grand National Assembly in 1934. In 1935, the Turkish women's movement gained international recognition as the International Women's Union held its $12^{\text {th }}$ Congress in İstanbul. ${ }^{1}$ In 1937 , Turkey

${ }^{1}$ S. Tekeli (ed.), Kadın Bakış Açısından Kadınlar: 1980 'ler Türkiye 'sinde Kadınlar ( $2^{\text {nd }}$ ed.), İstanbul, İletişim Yayınları, 1993, p. 14. 
became a secular state by law, culminating further relaxation of laws, and social norms which constrained women's full participation in the public life in Turkey. ${ }^{2}$ This was considered the start of a new phase for the Turkish feminist movement. The previous era witnessed substantial legal changes towards the equality of sexes. The new era was expected to bring about broader social change in the status of women. Turkish women entered education, employment, and other public domains of life in increasing numbers between the 1930s and the 1970s.

Following two decades of silence from the Turkish feminist movement during the 1950s and 1960s, the 1970s witnessed the emergence of a number of women writers who discussed the social problems facing women in capitalist society. ${ }^{3}$ These discussions reflected the emergence of the modern feminist, and socialist movements in the United States, Britain, France, Germany, the Netherlands, and other countries. However, influenced and informed more by Marxism than feminism, they argued that the capitalist economy sustained patriarchal relations in society, and thus equality could only be achieved through a new socialist formation of the society and the state. Because the Turkish feminist movement had allied itself with Marxism during the 1970s, the military coup in 1980 hit both the Marxists, and the Marxist-feminists severely. ${ }^{4}$ It is argued that not only did it silence and marginalize Marxist groups, but also it promoted so-called liberal Islamic formations in opposition to Marxism, and socialist-feminism.

Military rule ended and Turkish democracy was restored in 1983. The first government after the coup d'état implemented liberal, and laissez-faire policies which brought unforeseen changes to Turkish society. Both privately-owned and state-owned television, radio, and other mass media channels replaced the state monopoly in the 1980s. With the advent of the mass media, religion, the family, and sex

\footnotetext{
${ }^{2}$ N. Bilge, 'Laiklik ve Islamda Örtünme Sorunu', Cumhuriyet, January 31, 1995, p. 8.

${ }^{3}$ F. Akatlı, '1980 Sonrası Edebiyatımızda Kadın', Kadın Araştırmaları Dergisi, Vol. 2, 1994, pp. 29-40.

${ }^{4}$ Tekeli (ed.), Kadın Bakış Açısından Kadınlar, p.15.
} 
equality became hotly debated issues. ${ }^{5}$ During this time several feminist journals were published, and feminist arguments received wide media attention. Public debates resumed about feminist concerns ranging from women's employment, and domestic violence to the rights of sex workers. However, in the later part of the decade, these feminist groups fragmented, reflecting widening disparities in the fortunes of their supporters from different classes and ethnic groups, from rural, and urban areas, and from different educational backgrounds. Within this social framework, the hard-core feminist movement in Turkey was still dominated by an elite group of academics or well-educated women from the urban centres of Turkey. Thus, it enjoyed little success in reaching the lower socio-economic segments of Turkish society or in addressing their immediate concerns.

Despite a gradual improvement in awareness of sex equality in Turkey, protective legal provision against sex discrimination is still rudimentary. The Turkish constitution guarantees that women and men are equal, and enjoy equal rights. However, this legal understanding has not fully permeated to all the interstices of Turkish society, including employment. There are no equal opportunities laws to guarantee equal treatment at work in Turkey. Equality of opportunity in employment is neither actively supported nor protected by law. In practice, sex equality in the workplace is left to the ideological choice and good will of organisations at all levels of the labour process, and to the operation of the liberal economic system. International Helsinki Federation of Human Rights produced a comprehensive report on gender equality in Turkey in 2000 , which stated that:

Although, from a legal point of view, gender discrimination does not exist in terms of choosing and practising an occupation, women have frequently being excluded from decision making mechanisms and from certain professions. As a result, they have accepted low paid, low status work without insurance. Being the first to be fired during economic crisis, and being denied promotion regardless of

\footnotetext{
${ }^{5}$ Y. F. Ecevit, 'Kentsel Uretim Sürecinde Kadın Emeğinin Konumu ve Değişen Biçimleri', in Tekeli (ed.), Kadın Bakış Açısından Kadınlar, pp. 15-50.
} 
qualifications are the most common examples of gender discrimination in the workplace. ${ }^{6}$

There are some pieces of legislation relevant to sex equality, including firstly Article 26 of the Labour Code, which states that 'in the workplace different wages cannot be paid to female and male workers for the same quality of work with equal productivity only on the basis of gender difference'. Second, Article 70 the Labour Code regulates maternity leave, stating that female workers are prohibited from working six weeks before, and six weeks after giving birth. Third, Article 50 of the Constitution states that "no one shall be employed in work inappropriate to his/her age, gender, and physical strength. Minors and women along with physically and mentally disabled are specifically protected in terms of working conditions. In addition, Articles 68 and 69 of the Labour Code outline the sectors and conditions which are deemed inappropriate for women. These include mines, cable laying, sewage system, tunnel construction, and other underground and underwater operations, fire services, the metal and chemistry industry, construction work, work involving night shifts, and garbage collection. ${ }^{7}$ There are still organisations in Turkey which employ no women at all, justified by these protective legal provisions, their so-called religious beliefs, organisational cultures or traditions, yet there is no legal scope to challenge their practices. ${ }^{8}$

While the legal framework of equality in Turkey has been lagging behind that of its European counterparts for the last three decades, sex equality practice was also hampered by three socioeconomic developments during this time. First, the country has been experiencing chronic recession, and this had a gendered impact on women and men's employment opportunities. Second, migration both from rural to urban areas, and internationally had a disproportionately adverse affect on the female population. Finally, the resurgence of right wing religious and nationalist politics in Turkey have posed a challenge to the fragile mechanisms of sex equality in the country.

\footnotetext{
${ }^{6}$ International Helsinki Federation of Human Rights, Women 2000: An Investigation Into the Status of Women's Rights in Central and South-Eastern Europe and the Newly Independent Status, Vienna, 2000, p. 445.

${ }^{7}$ Ibid., pp. 445-446.

${ }^{8}$ Ibid., p. 446.
} 
Figure 1. Ratio of female population in economically active population (1955-1998)

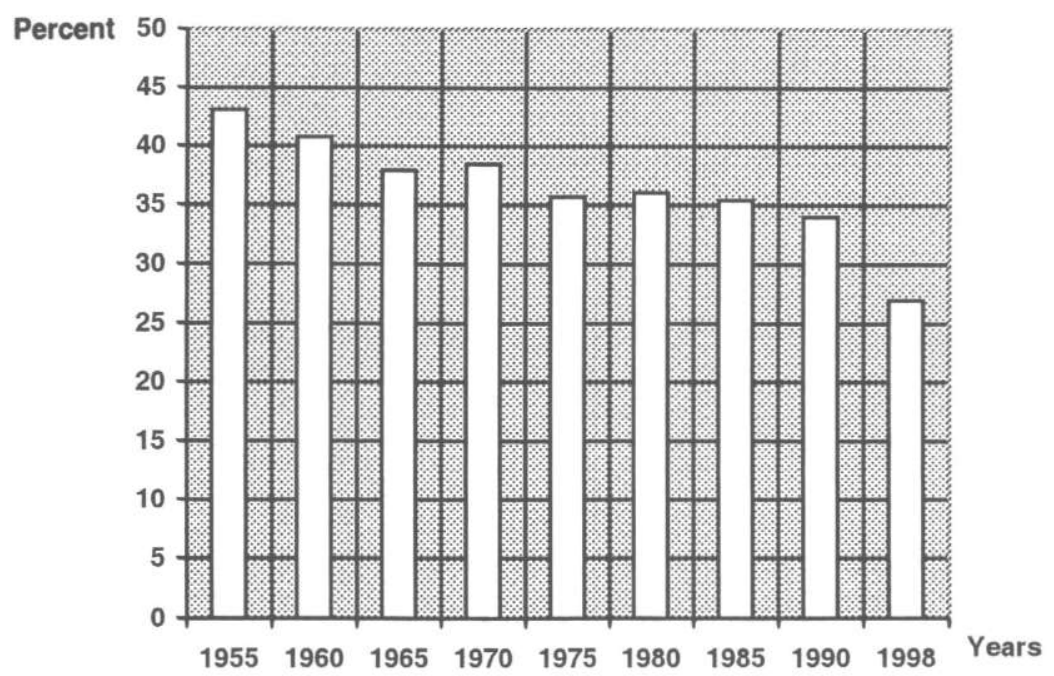

Source: DIE Women In Statistics, 1927-1992, Ankara, DIE Press, 1995, pp. 22-23.

The proportion of women who are economically active in Turkey has for a number of years been declining relative to men. ${ }^{9}$ While 95 percent of the adult male population participated in the labour force in 1955, this figure had decreased to 78 percent by 1990 . Women's participation decreased even more rapidly, from 72 percent to 42 percent over the same period. ${ }^{10}$ Figure 1 illustrates that while women constituted 43 percent of the economically active population in Turkey in 1955, this was only 27 percent in 1998. Coupled with the gendered impact of recession, the gender gap in pay continues to be a problem for Turkish women, whose non-agricultural wage in proportion to men's stands at 84.5 percent. This is higher than the international ratio of 74.9 percent. However, Turkish men still enjoy higher absolute wages than Turkish women. ${ }^{11}$ Thus, the economic

${ }^{9}$ DIE (State Institute of Statistics of Turkey), Women in Statistics 1927-1992, Ankara, DIE Press, 1995.

${ }^{10}$ DIE, Statistical Indicators 1923-1991, Ankara, DIE Press, 1993.

${ }^{11}$ United Nations, Human Development Report, New York, United Nations Publications, 1995. 
recession has affected women's access to employment to a greater extent than men. Due to economic recession since the 1960s, and the lack of progressive legislation, it is becoming increasingly difficult for Turkish government to prioritise an agenda of sex equality over macro economic concerns of the country. An agenda of sex equality, therefore needs to be mainstreamed into national programmes of economic development, if it were to be successful.

The second striking national phenomenon affecting women's employment since the 1970 s, together with the negative social effects of the economic recession, has been the acceleration of the migration from rural to urban areas. In 1992, Turkey had a growing population of 58 million, of whom 31 million lived in cities, and 27 million in rural communities. ${ }^{12}$ In the last decade, a desire for the economic, social, and cultural conveniences of the city promoted by the mass media, renewed ethnic conflicts, human rights violations, and military action against the PKK in the South-east Turkey, have all fuelled social mobility and migration from rural to urban centres. While the country's urban population constituted 23.5 percent of the total population of 14 million in 1935 , by 1990 this had increased to 59 percent of 56 million (See Table 1). ${ }^{13}$ The phenomenal growth of urban areas in an unplanned fashion, and the relatively youthful profile of the country's population, have brought unexpected social and political consequences. The mass migration to cities has led to proliferation of shantytowns at the peripheries of urban centres. The shantytowns grew in an unprecedented and unplanned fashion during the 1980s and the 1990s. These areas were deprived of key public services such as health, education, and transportation. Most men and women, who sought internal migration from rural to urban areas, were from farming communities. Their agrarian backgrounds deemed their skills redundant, and their social integration difficult in urban areas. Therefore, migration caused deskilling, and social exclusion for the migrant population. Erman, ${ }^{14}$ in her groundbreaking work on squatter studies in Turkey, argued that the academic treatment of shantytown

${ }^{12}$ DIE, Household Labour Force Survey Results, Ankara, DIE Press, 1994.

${ }^{13}$ DIE, Women In Statistics, 1995, pp. 22-23.

${ }^{14} \mathrm{~T}$. Erman, 'The Politics of Squatter Studies in Turkey: The Changing Representations of Rural Migrants in the Academic Discourse', Urban Studies, Vol. 38 (7), 2001, pp. 983-1002. 
people in Turkey also contributed to their marginalization, as they have been consistently treated as the 'inferior other' by the Turkish researchers. Based on Gunter's ${ }^{15}$ evaluation of current political developments, reversal of migration could be possible, because ethnic, and military conflict in south-east Turkey has come to an end, and Turkey's European Union candidacy bid is linked to its democratisation process.

Table 1. Proportion of the Turkish population in cities and villages

\begin{tabular}{ccc}
\hline $\begin{array}{c}\text { Census } \\
\text { Year }\end{array}$ & City (percent) & Village (percent) \\
\hline 1935 & 23.5 & 76.5 \\
1940 & 24.4 & 75.6 \\
1945 & 24.9 & 75.1 \\
1950 & 25.0 & 75.0 \\
1955 & 28.8 & 71.2 \\
1960 & 31.9 & 68.1 \\
1965 & 34.4 & 65.6 \\
1970 & 38.3 & 61.7 \\
1975 & 41.8 & 58.2 \\
1980 & 43.9 & 56.1 \\
1985 & 53.0 & 47.0 \\
1990 & 59.0 & 41.0 \\
\hline
\end{tabular}

Source: DIE, Household Labour Force Survey Results, Ankara, DIE Press, 1992, p. 20.

Women have been influenced by this massive migration to cities in two main ways. The common pattern of migration for members of the lower socio-economic classes starts with the migration of the men, who then try to achieve economic and social survival in the city in order subsequently to bring their families to join them. In this pattern, women face the new urban social and economic conditions later than men, and are reduced to financial dependence on the men who brought them to the city. This trend is observable in the statistics: women

${ }^{15}$ M. M. Gunter, 'The Continuing Kurdish Problem in Turkey After Ocalan's Capture', Third World Quarterly, Vol. 21 (5), 2000, pp. 849-869. 
constituted 48.8 percent of the urban, and 51.2 percent of the rural population in 1992, and while men's labour force participation in the cities was 69.2 percent and women's 16.1 percent, the figures for rural men's labour force participation was 76.6 percent and women was 50.2 percent. ${ }^{16}$ Secondly, Turkish cities do not offer adequate employment opportunities for poorly educated labour, as their labour requirements are for a more skilled and educated work force than in rural areas. Furthermore, sex segregation and discrimination in unskilled jobs is even stronger than for highly skilled jobs. ${ }^{17}$ While women's unemployment rate was 20.5 percent in the cities and 2.5 percent in the villages, men's unemployment rate was 9.8 in the cities and 6.2 in the villages in $1992 .{ }^{18}$ Migration causes migrant women who were economically active in the rural economy either to lose the skills that they were able to use in agriculture, and the household economy, or to suffer exploitation by becoming piece-work or temporary workers without adequate pay or social security. In either case, their economic and social dependence on husbands and fathers are increased. Table 2 provides numerical evidence of the gendered impact of migration in Turkey. It indicates that Turkish women outnumber men in agricultural sector in rural areas, and that they are highly underrepresented in industrial and service sectors, which are mostly located in urban areas. It is important to note that any national agenda of sex equality should address the gendered impact of migration, and issues of women with low as well as high human capital.

${ }^{16}$ DIE, Work Statistics, Ankara, DIE Press, 1994.

${ }^{17}$ D. Kandiyoti, Cariyeler, Bacılar, Yurttaşlar: Kimlikler ve Toplumsal Dönüşümler, İstanbul, Metis Yayınları, 1997.

${ }^{18}$ DIE, Work Statistics, p. xi. 
Table 2. Employed person by economic activity in Turkey in 1990-1998 (percent)

Indicators

Agriculture

Industry

Services

\begin{tabular}{lc}
\multicolumn{2}{c}{ October $\mathbf{1 9 9 0}$} \\
Female & Male \\
75.8 & 33.6 \\
9.8 & 26.8 \\
14.4 & 39.6
\end{tabular}

October 1998

Female Male

$70.0 \quad 32.6$

$10.6 \quad 27.2$

$19.4 \quad 40.2$

Source: DIE Household Labour Force Survey, Ankara, DIE Press, 2000, p. 8.

Resurgence of the religious right in Turkey is the third major factor threatening sex equality in Turkey. In the 1990s, the rise of the religious, and nationalist right in Turkey was often attributed to adverse affects of neo-liberal structuring, mass migration, and economic recession. ${ }^{19}$ Therefore it was initially considered a temporary social problem for Turkey. In the 1991 General Elections, women's issues were included in the campaigns of all the major political parties. However, the religious right was more successful than others in addressing the problems facing women from the lower socio-economic classes, from ethnic minority and migrant backgrounds, groups which the other feminist movements in Turkey have largely ignored ${ }^{20}$ Öniş calls these methods of political campaigning as 'religious nationalism', and 'cross-class alliance'. ${ }^{21}$ The political agenda of religious right in Turkey involved women's issues ranging from migration, the recession, sexual trafficking, health, and employment, as part of their party propaganda. They emulated socialist and feminist discourses to attract supporters from those marginalized segments of the society which have been ignored by the mainstream parties of the 1990s. ${ }^{22}$ However, the

${ }^{19} \mathrm{Z}$. Öniş, ' The Political Economy of Islamic Resurgence in Turkey: The Rise of The Welfare Party in Perspective', Third World Quarterly, Vol. 18(4), 1997, pp. 743-766.

${ }^{20}$ Y. Arat, " The Patriarchal Paradox: Women Politicians in Turkey ('Patriyarkal Paradoks: Türkiye'de Kadın Politikacılar', translated into Turkish by Fatmagül Berktay), Kadın Araştırmalarn Dergisi, Vol. 1, pp. 137-140.

${ }^{21}$ Öniş, The Political Economy, p. 753.

${ }^{22}$ H. Yeşil, Sosyalist Kadın Hareketi Için, İstanbul, Dönüşüm Yayınlan, 1992, pp. 166-168. 
remedies, which they proposed, were of traditional nature, offering no progressive solutions for working women's problems. Similarly the nationalist movement, which had increased popularity in the second half of the 1990s and the early 2000s, did not offer a significant transformational agenda of sex equality. It is interesting to note that within the female wing of the so-called Islamist political parties, i.e. Refah, and Fazilet different and often conflicting ideologies, regarding women and employment, co-existed. ${ }^{23}$

The spectrum of ideologies within these parties ranged from Conservative Islamist, which suggests that women's role in society is to be 'good' mothers, wives, and Muslims, to Feminist Islamist, which argued for a wider range of socio-economic benefits for women based on the re-interpretation of the fundamental religious doctrines, and the 'decontamination' of texts and doctrines from their prevailing male bias. The Refah Party was closed down in 1997, and its predecessor Fazilet Party in 2001, by the orders of the Constitutional Court, acting on the basis of allegations, and evidence of fraud and misconduct in their funding, and rallying methods. Although this was welcomed within the secularist circles of Turkey, to close down two political parties of this level of popularity posed a threat to the democratic process, and may result in reactionary underground activities. The future of political Islam, and the Islamic feminism which was becoming aligned with it, is currently difficult to predict.

At the backdrop of these mitigating social, economic, and political circumstances, there are also strong drivers for sex equality in Turkey. Turkey is signatory of various international agreements and conventions which aim to promote sex equality. Secondly, a directorate of sex equality, which operates as the national machinery, was established in 1990. Third, feminist activism continues to challenge gendered inequalities in Turkey. It was argued earlier that the legal provision of sex equality in Turkey is lagging behind that of its European counterparts. Thus the international environment within which Turkey is a player has an essential role in closing this legal gap by encouraging enactment of sex equality legislation in Turkey. Turkey has ratified several relevant international treaties and conventions,

${ }^{23}$ N. Göle, Modern Mahrem: Medeniyet ve Örtünme (4 $4^{\text {th }}$ ed.), İstanbul, Metis Yayınları,1993. 
including the European Convention of Human Rights and Fundamental Freedoms, the Universal Declaration of Human Rights, the Charter of the United Nations, and most recently, in 1986, the Convention on the Elimination of All Forms of Discrimination Against Women (CEDAW). CEDAW is considered of particular importance in demonstrating the Turkish government's commitment to sex equality. However, it should be noted that implementation of these conventions need to follow suit, if they are to make a real impact. ${ }^{24}$

European Union has made much progress in 2000 in equal opportunities, producing two directives and a proposal for community action programme to combat discrimination. ${ }^{25}$ Since 2000, increased relations between Turkey and Europe have been providing a strong push for democratisation and pluralism in Turkey. ${ }^{26}$ As the longest standing applicant country to the European Union membership, the Turkish government needs to fulfil a set of accession criteria, which are commonly referred to as the Copenhagen criteria in the process of accession to membership. The European Union produces progressmonitoring reports, which evaluate how the candidate countries measure up against these criteria. The annual report on Turkey in 2000 considered undersigning of the CEDAW a welcome development for Turkey. However, the report was also critical as it provided both social and legal insights into perceived shortcomings of sex equality practice and legislation in Turkey:27

As regards equal opportunities, gender disparity is still high. The illiteracy rate is roughly 25 percent for women, and 6 percent for men, due to low school enrolment rates for girls, particularly in

${ }^{24}$ D. Woodward and M. Özbilgin, 'Sex Equality in the Financial Services Sector in Turkey and the UK', Women in Management Review, Vol. 18(8), 1999, pp. 325332.

${ }^{25}$ EIRO (European Industrial Relations Observatory) Annual Review 2000, A Review of the Development in European Industrial Relations, Luxemburg, Office for Official Publications of the European Communities, 2001, p. 42.

${ }^{26} \mathrm{C}$. Rumford, 'Human Rights and Democratisation in Turkey in the Context of European Union Candidature', Journal of European Area Studies, Vol. 9 (1), 2001, pp. 93-105.

${ }^{27}$ European Union Commission of Turkey, Report on Turkey's Progress Toward Accession 2000, Geneva, 2001, pp. 18-19. 
Eastern Turkey. There is still a need for further action to improve the educational position of women. In terms of equality of treatment, conformity with the EC acquits, its not yet ensured... As far as the Civil Code is concerned, certain legal discrimination between men, and women (notably concerning the family, and working life of women) persist. The current regime foresees, for example that the husband is the head of the family, and alone represents the union produced by marriage. The husband, as head of the family, is then the one that holds the right to legal custody of minors. Amendments to the Civil Code have been prepared with contributions from Women's NGO's, and are under discussion in the Parliament. The question of violence against women within the family, including socalled "honour killings", is still an issue of serious concern.

The report clearly states that there is a need for specific legislation to protect and promote sex equality in Turkey, if conformity to European Community acquits is to be achieved. The report highlights a need for structural, and as well as legislative reforms: ${ }^{28}$

In the area of equality of treatment no further transposition of EC legislation can be reported... The Turkish Constitution guarantees gender equality, and lays down the principle of non-discrimination. However, efforts are needed to ensure implementation, and enforcement of equality of treatment. In particular actions should be envisaged to reduce female illiteracy, and promote urban employment for women through education, and training.

Despite growing relations between Turkey and the European Union, some of the current literature on enlargement in the European Union publications, and the academic works, i.e. Watson, ${ }^{29}$ continue to discount Turkey in their analysis. Nevertheless, the partnership process, and other national and international catalysts of change will encourage Turkey to legislate on equal opportunities. In the 80 years of the Turkish Republic, principles of sex equality were promoted by a republican and secularist state ideology, without recourse to legislation. However, this ideological stance is weakening due to the aforementioned social, economic, and political challenges that mitigate

${ }^{28}$ European Union Commission on Turkey, Report on Turkey's Progress, pp. 49-50.

${ }^{29} \mathrm{P}$. Watson, 'Politics, Policy and Identity: EU Eastern Enlargement and East-West Differences, Journal of European Public Policy, Vol. 7(3), pp. 369-384. 
against the traditional state ideology of sex equality. Counterbalancing the gendered impact of these changes increasingly requires Turkish government to support sex equality through specific legislation. In order to satisfy the conditions of these international agreements, and to complement her aspirations to join the European Union, the Turkish government established the Directorate General on the Status and Problems of Women, which is directly affiliated to the Prime Ministry, in 1990. The Directorate has 'a specific mandate to ensuring the rightful status of women, and gender equality in the social, economic, cultural, economic, and political fields' ${ }^{30}$ The directorate aims to provide a national machinery for sex equality, offering training programmes to encourage and support women's active participation in these fields, and overseeing number of national programmes of development. Its presence is increasingly felt with opening of 12 provincial administrations. The directorate also commissions a number of research publications each year ${ }^{31}$ However, the limited authority, and scope that is afforded to the directorate, and the meagre funding it was allowed from the national budget have been repeatedly criticised. Although the government is taking several positive steps by establishing a directorate for equality, and undersigning international conventions, if these are to make an impact, adequate resources should be allocated, and structural changes should be made to strengthen their position.

The third positive push factor for sex equality in Turkey is the activities of the non-governmental women's organisations. The contemporary Turkish feminist movement embraces a wide diversity of political and ideological stances. These groups range from conservative and liberal Islamist feminists ${ }^{32}$ to radical and socialist feminists, ${ }^{33}$ and they subscribe to radically different conservative or progressive definitions of, and aspirations for, sex equality and women's position within Turkish society and work life.

${ }^{30}$ DGSPW (Directorate General on Status and Problems of Women in Turkey), Report on Women in Turkey, Ankara, DGSPW Press, 1999, p. 4.

${ }^{31}$ DGSPW, Türkiye 'de Kadinlara Ait Girisimlerin Desteklenmesi, Ankara, DGSPW Press, 2000.

${ }^{32}$ Y. Arat 'Islamic Fundamentalism and Women in Turkey', The Muslim World, Vol. LXXX ( 1), January, 1990.

33 Arat, 'The Patriarchal Paradox', 1994. 
Recent social trends indicate that Turkey is once more at the cross-roads of tradition, and modernisation, religion and secularism, east and west, democracy and totalitarianism. Various groups within the Turkish feminist movement are working to redefine the politics of sex segregation. These are all progressive moves towards creating a legal framework for equal opportunities in employment. Yet the very diversity of these groups, and their consequent incapacity to organise effectively to influence the current male-dominated environment of Turkish politics dooms their efforts to ineffectuality. It is possible to identify two forms of sex equality activism in Turkey: A relatively more traditional one emanating from the women's rights movement in Turkey, and another form of activism emulating the discourse and language of the contemporary Anglo-Saxon dominant approaches to sex equality in a Turkish context. These two forms of activism have different traditions of discourse and practice. The former approach, namely the women's rights activism in Turkey, dates back to the later periods of the Ottoman Empire. Its main aim has been to contribute to the national project of modernisation. This contribution would be achieved through elimination of explicit barriers to women's entry to paid employment, and their contribution to economic production in Turkey. Thus, the movement has rationalised its existence by aligning itself with the national plans of modernisation, and development in Turkey.

The latter movement of equal opportunities by sex is a more contemporary development in Turkey. This approach is loosely linked to national development plans in Turkey, and promotes an ethical case for equality, using Anglo-Saxon notions of discrimination, social justice, and equality. This approach may be mainstreamed in policy making, and implementation at state level, if the Turkish government produces the sex equality laws in line with the European Union legislation. A similar differentiation is also visible in the sex equality discourse in Turkey. While, publications frequently referred to women's rights at work in Turkey prior to the 1980s, adoption of the term 'equal opportunities' is a new phenomenon in the context of employment. Before the 1990s', the term 'equal opportunities' was predominantly used in explaining issues of access to educational opportunities in Turkey. The business literature seldom referred to issues of sex equality at work in the Turkish context. This literature 
adopted an approach based on 'women's rights at work', focusing on explicit forms of employment discrimination, and failing to problematize the gendered nature of work, and employment experiences. Indeed, considering equality as a women-only issue fails to recognise that sex equality promises a positive change in men as well as women's lives, as it is concerned with better recognition, and accommodation of varied work-life roles such as domestic work, caring roles, and paid work.

Despite evidence of increased international, and national push for equality, the current status of sex equality should not be over estimated. Information on international agreements, the national mechanisms of sex equality, and the rights they promise for women and men are sparse, and feminist activism is limited in scope and its social reach in Turkey. The information on sex equality rights in Turkey is made neither accessible nor available. They benefit articulate and wellinformed women from the higher socio-economic classes of Turkish society, but fail to address the problems and concerns of the rest of the female population, who are not aware of their rights, and so are unable to exercise them due to their disadvantaged economic and social status. Moreover, although there is an organisation for equality, it is centrally managed from Ankara, serving only small communities, rather than the whole female population. It seems that within this social spectrum of ideologies, women's problems have been used as a platform for enhancing men's political ambitions, and ends, rather than promoting real solutions to the legal and social inequalities that disadvantage women in modern Turkey. It is interesting that these wider social, religious, and nationalist movements, based on man-made ideologies of male supremacy, once again incorporated feminist concerns into their agendas in order to attract women supporters, but at the same time they failed to address women's real-life problems. This suggests that there is a need for a stronger political and social movement which can cater for the expectations of the women from the lower socio-economic classes, from ethnic and sexual minorities, as well as from the privileged segments of the society, in order to challenge the current legal and social systems that sustain these unequal social divisions. 


\section{Sex Equality in Britain}

It is possible to identify the origins of modern feminism in the suffrage movement of the late $18^{\text {th }}$, and early $19^{\text {th }}$ centuries. The role of the Enlightenment in establishing the intellectual roots of the modern feminist movement in Britain has been identified in earlier works. However, as Caine explained, ${ }^{34}$ this argument is probably incorrect:

Nowhere is the importance of potential change more marked than in regard to the late eighteenth century, and the Enlightenment... Modern feminism has thus come to be seen not as a simple outgrowth of the Enlightenment, and the French Revolution, but rather as a consequence of the new forms of discrimination which women faced at this time when they were explicitly denied rights being granted to men under bourgeois law. It was this new discrimination which provided the stimulus for feminist demands in Britain as in France, and America.

This feminist movement of the $18^{\text {th }}$, and early $19^{\text {th }}$ centuries thus prepared the ground for first wave feminism, both in Britain, and the USA, which promoted a new political identity for women, and mobilised them to seek legal, and social rights, which would put them in the same position as their male counterparts. Although both the antislavery movement in the USA, and political agitation in mainland Europe in the 1840s have been identified as the origins of the first wave feminist movement, Davis warned against such association between 'blacks' and 'women', as conducive to unconscious racism, and false universalization. ${ }^{35}$

The first wave feminist movement in Britain was represented by the organisations such as WSPU (Women's Social, and Political League); WFL (Women's Freedom League); NUWSS (National Union of Women's Suffrage Societies), and the Women's Co-operative Guild, as well as the WILPF (Women's International League for Peace and Freedom). Alice Paul, one of the central figures of the movement, founded the Woman's Party in 1914. The political activities carried out

${ }^{34}$ B. Caine, English Feminism: 1780-1980, Oxford, Oxford University Press, 1997, pp. 4-5.

${ }^{35}$ A. Davis, Women Race and Class, New York, Random House, 1981. 
by the members of these groups, such as petitions, demonstrations, and campaigns for the vote for women, and subsequently for women's rights in both the public and private spheres, were influential in achieving certain legal and political rights for women between the years of 1880 and 1928, until women won the franchise on same terms as men in the Equal Franchise Act of 1928. The National Union of Societies for Equal Citizenship (NSEC), led by Eleanor Rathbone, played a major role in winning women the franchise. This was considered as the ultimate aim by many of the liberal activists of the time, who then organised to teach women how to use their vote, and the importance of it. This first wave of feminist movement prepared the ground for women's entry into occupations, and witnessed the opening of some professions, and opportunities for advanced education to women.

The first wave feminist movement coincided with the later years of the Industrial Revolution in Britain, which had its own set of consequences for women's participation in economic activity. Humphries explored the key census data concerning women's participation to employment in Britain, in her ground-breaking historical study of women, and paid work. Contrary to common assumptions, she argued that: ${ }^{36}$

...women were active economically in the period of the Industrial Revolution, more active than they were to become by the end of the nineteenth century, and more active then they were to be in the first three decades of the twentieth. Unfortunately, we have no way of comparing this period with earlier in the eighteenth century, and so cannot comment on whether early industrialisation elevated women's activity rates. But far from destroying women's jobs, and driving them out of paid work, industrialisation seems to have sustained relatively high activity rates... Industrialisation undoubtedly eliminated some women's work. Hand spinning is the obvious, but not only, example. Overwhelming evidence also exists to suggest that women's jobs in agriculture were also reduced. But industrialisation also created jobs for women. Factory production of textiles is again an obvious example, but others could be cited. ${ }^{37}$

\footnotetext{
36J. Humphries 'Women and Paid Work', in J. Purvis (ed.) Women's History: Britain 1850-1945, London, UCL Press, 1996, pp. 85-106.

${ }^{37}$ Ibid., p. 98.
} 
Despite poor documentation of women's labour force participation prior to, and during the Industrial Revolution, Humphries re-examined census data, and other relevant historical documentation. ${ }^{38} \mathrm{Her}$ estimates suggested that, although women's activity rates were high at the beginning of the Industrial Revolution, they declined between 1846 and 1881, not least because of barriers to women's mobility.

Women, then as now, were less geographically mobile than men. Married women could only move with their families, while young women moving on their own were very vulnerable. Significantly, the most rapidly growing job for women, domestic service, was one that eased the strain of moving to a strange place, and acquiring a new home. ${ }^{39}$ There are parallels with the contemporary Turkish situation, where women are often pushed out of employment during urbanisation, due to the social, traditional, and religious constraints imposed on their mobility, and career choices.

Although the first wave feminist movement promoted women's entry to professional careers, and other employment in Britain, women's general participation in the labour force in fact declined during, and after the First World War. ${ }^{40}$ After the First World War, British society experienced a major social change as the ratio of women to men in the population increased due to wartime losses in the male population. While there were 6.8 percent more women than men in 1911 in Britain, by 1920 this excess increased to 9.6 percent. ${ }^{41}$ Considering that the majority of the population married at a younger age than their contemporary counterparts, and that there were too few men to enable all women who wished to do so to marry, sustaining economic independence became a concern for increasing numbers of single women after the war years. The removal of the Sex Disqualification Act in 1919, allowed women to enter the legal profession, and the election of the first women to parliament

\footnotetext{
${ }^{38}$ Tbid., p. 99.

${ }^{39}$ Ibid., p. 99.

${ }^{40}$ Ibid., p. 93.

${ }^{41} \mathrm{~J}$. Lewis, Women in England 1870- 1950, Brighton, Wheatsheaf Books, 1984, p. 4.
} 
immediately after the First World War, coupled with weakening social controls, allowed single women to resume paid work after the war. Although many married women returned to full-time homemaking, the aftermath of the First World War witnessed promising developments promoting the economic independence of single women.

During the Second World War, women once again entered formerly male-dominated occupations in large numbers. After the war, women's employment received much popular attention, and sex inequalities in pay became a matter for discussion. The Equal Pay Campaign Committee, formed by over hundred women's organisations in 1943, led to two progressive measures in the subsequent years: equal pay was accepted for teachers in 1952, and for Civil Service employees in 1954. However, the Committee dissolved itself after these modest gains. ${ }^{42}$ These limited achievements must be set against other, reactionary developments. In the same period, the Beveridge Report (1942), which was part of the development plan for the Welfare State advocated by the reforming Labour government, shaped women's entitlement to welfare benefits based on traditional notions of 'the family' ${ }^{43}$ Similarly, the marriage bars introduced in certain occupations during the inter-war period, in response to recession, were only removed gradually, finally ending in the $1950 \mathrm{~s}$. Some of the legislation to come out of post-war welfare reform, such as the Butler Education Act (1942), proposed free secondary education for all citizens. This was highly influential in expanding education opportunities for women. The main discourse used for sex equality during this period was based on individualist morals and individual freedoms, which are the basis of liberal feminist arguments. The liberal ideology of the time thus promoted women's opportunities in both education and employment.

Although women's participation in economic activity in Britain increased after the Second World War, its significance has been questioned by Braybon, ${ }^{44}$ who argued that this increase in women's

\footnotetext{
${ }^{42}$ Caine, English Feminism, pp. 232-233.

${ }^{43} \mathrm{R}$. Crompton and K Sanderson, The Gendered Restructuring of Work in the Finance Sector', in A. M. Scott (ed.), Gender, Segregation and Social Change, Oxford, Oxford University Press, 1994, p. 50.

${ }^{44} \mathrm{G}$. Braybon, Women in the First World War, London, McMillian, 1989.
} 
employment was mostly in temporary, voluntary, and underpaid jobs, which did not bring much improvement in women's economic status. In the 1960s, and 1970s, women's jobs were usually located firmly at the bottom of the organisational hierarchies. As late as the 1960s, they were still expected to leave employment after marriage, or prior to the birth of their first child. ${ }^{45}$

In Britain, the concept of equal opportunity in employment informed legislation in the 1970s fuelled by the women's liberation movement, which itself grew from the democratic, anti-war, and antiracist movements of the time. The institutionalisation of debate about sex equality leading to changes in employment policy and practice began in the British public sector, and later gained acceptance within the private sector.

In the 1970 s, as Crompton, and Sanderson suggested, ${ }^{46}$ 'the social citizenship of women was confirmed by legislation' in Britain. The first equal opportunities law to be enacted as an outcome of these efforts was the Equal Pay Act in 1970 (amended in 1983). This law covered various aspects of equal pay including holiday entitlements and sick pay. The British government joined the European Community, signing the Treaty of Rome in 1972. Article 119 of the treaty states that women and men should receive equal pay for equal work. The article was originally crafted to curb unfair economic advantages of employing cheap female labour in the European Community. Nevertheless, it was instrumental in committing nation states to further legislation in this field. The European Union has also passed several other directives regarding sex discrimination. Britain, as a member state, pledges compliance with these directives. European Union legislation therefore has become a driving force for legislation against sex discrimination in Britain. ${ }^{47}$

${ }^{45}$ S Halford, M. Savage and A. Witz, Gender Careers and Organizations : Current Developments in Banking, Nursing and Local Government, London, MacMillan, 1989.

${ }^{46}$ Crompton and Sanderson, The Gendered Restructing of Work, p. 53.

${ }^{47}$ L. Clarke, ' The Role of The Law in Equal Opportunities', in Making Gender Work: Managing Equal Opportunities, Buckingham, Open University Press, 1995, p. 63. 
The Equal Pay Act 1970 is often referred to as the first piece of significant legislation on sex equality in Britain. The Sex Discrimination Act 1975 (amended in 1986) followed this first legislation. Racial equality entered the legislative agenda in 1976 with the passage of the Race Relations Act. The Disability Discrimination Act (1995), and the Pensions Act (1995) have been enacted in recent years to promote equality by physical disposition and age. Although Britain has established this raft of equality legislation on sex, race, and disability discrimination, British laws do not yet discourage discrimination on the grounds of sexual orientation. Equal Opportunities Commission which was established to oversee the implementation of the Sex Discrimination Act, and the Equal Pay Act reported limited success in closing the pay gap in Britain. The gap between men and women's earnings narrowed from 31 percent to 18 percent since 1970. When part-time working is included, the pay gap is said to be still the widest in any state in the European Union. ${ }^{48}$

Britain ratified the European Convention on Human Rights and Fundamental Freedoms in 2001. The charter includes a wide range of employment and industrial relations rights that were also found in a range of national and international instruments. ${ }^{49}$ This means that by December 2003, Britain will align its equal opportunities legislation to offer protection against sexual orientation discrimination as well as other forms of unfair discrimination. However, this convention was criticised by the United Nations Committee on Elimination of Discrimination Against Women for its failure to assign active roles, and duties to the European governments to eliminate indirect forms of sex discrimination. ${ }^{50}$ The Committee of the CEDAW concluded that Britain satisfied many of the structural requirements of the convention. However, the committee made several hefty recommendations including elimination of gendered impacts of devolution in Britain.

${ }^{48}$ EIRO (European Industrial Relations Observatory) Observer, Nice Summit Agrees New Treaty and Rights, Issue: 1/01, Geneva, 2001, pp. 10-11.

${ }^{49}$ EIRO, Observer, EOC Urges New Action on Equal Pay, Issue: 3/01, Geneva, 2001, pp. 2-3.

${ }^{50}$ CEDAW (Committee on the Elimination of Discrimination Against Women), Concluding Observations of the Committee on the Elimination of Discrimination Against Women; United Kingdom of Great Britain and Northern Ireland, United Nations Reports, A/54/38, New York, 1999, pp. 278-318. 
Since the elections in 1997, the Labour Government took effective steps to proceed with devolution of Wales, Scotland, and Northern Ireland. These regions now implement a range of approaches to management of equal opportunities. This political change implies that equality agendas may become uneven across these regions. The committee also commented on under-representation of women in public and political life, in the judiciary, in positions of higher education, and in other areas, and continuing pay gap between male and female workers. The committee also identified some social, and economic issues which adversely impact on women's life as well as career opportunities. The report recommends British government to take effective steps to tackle problems of teenage conception, violence against women, and women's poverty through multi-agency approaches. The international push that the CEDAW offers is substantial, and promising for both Britain and Turkey. However, as the reports for both countries indicate, the governments should take effective steps to eliminate discrimination, and make the concluding remarks and recommendations of the periodic reviews more widely available throughout their countries.

Starting with the enactment of the Equal Pay Act (1970), and the establishment of the Industrial Tribunal system, equal opportunity became a part of standard employment discourse in business and industry in Britain. While some employers chose minimal compliance with these laws, others employed more progressive strategies to tackle sex discrimination at work. The rise in the number of cases taken to Industrial Tribunals suggests that there is now a better awareness of the available mechanisms, and also that the legislation has not yet obliterated practices of sex discrimination. The current framework of equal opportunities legislation, and the role of the Equal Opportunities Commission have been criticised for failing to achieve substantial progress towards sex equality. Clarke insightfully criticised the overall perspective of the equal opportunities adopted in British legislation: ${ }^{51}$

Sex discrimination law in the UK begins from the classical liberal principle that similarly situated individuals should be treated alike, whereas differently situated individuals should be treated differently.... The model of 'sameness', that sex is a suspect

\footnotetext{
${ }^{51}$ Clarke, 'The Role of the Law in Equal Opportunities', 1995, p. 55.
} 
clarification which simply needs to be ignored in order to achieve equality, fails to address the reality that women's lives are different from men's; it aspires to an assimilationist model that takes the male role as the norm, and aims to encourage, and enable women to be just like men.

Cockburn explained the reasons why the current legal framework of equal opportunities cannot induce positive change: ${ }^{52}$

The law is too weak, and difficult to use. Organisations taking positive action are too few, and their goals, and methods too limited. Organisations chose high profile, cost-free measures, and neglect the more expensive changes that would improve things for a greater number of women. Policies adopted are seldom implemented. Implementation is not monitored. Non-compliance is not penalised, nor is co-operation rewarded.

Although equal opportunities legislation may have failed to transform gendered employment practices in British industry, and business, it was instrumental in promoting public debate, and the dissemination of an equal opportunities literature which was influential in the 1980s and 1990s in encouraging women to aspire to, and penetrate into the senior ranks of many organisations.

In Britain, the notion of equal opportunities management entered business language in the 1980s. Many companies employing large numbers of workers have established equal opportunities departments, which were instrumental in ensuring that the organisation's position on equality is understood, and implemented at all levels of employment. Although the implementation of equal opportunities legislation varied widely between different organisations, and also within them, Davidson and Cooper suggested that increasing numbers of women succeeded in obtaining senior posts within organisations in this period. ${ }^{53}$ Between 1973 and 1993, while adult women's economic activity rates increased from 63 percent to 71 percent, men's participation has decreased from

${ }^{52} \mathrm{C}$. Cockburn, In the Way of Women: Men's Resistance To Sex Equality In Organizations, London, McMillian, 1991, p. 225.

${ }^{53}$ M. J. Davidson and C. L. Cooper, Shattering The Glass Ceiling: The Women Manager, London, Paul Chapman Publishing Ltd., 1992. 
91 percent to 86 percent in the same period ${ }^{54}$. In 1994, the economic activity rates for women between the age of 16 , and 65 was 71 percent, while that of men was 85 percent. ${ }^{55}$ Perrons and Shaw suggested that, if this trend continues, the economic activity rates of women, and men will converge at 75 percent sometime in the next decade. ${ }^{56}$

However, it should be noted that a rise in the economic activity rate of women does not of itself affect the quality of women's employment experience. Despite over three decades of legislation intended to promote sex equality in employment, labour market statistics suggest that both vertical and horizontal sex segregation, as well as sex inequalities in pay persist. ${ }^{57}$ Fewer women than men occupy higher grade posts: while 32 percent of managers and administrators are women, fully 79 percent of them are working as administrators, and merely 21 percent are managers. ${ }^{58}$ Another important trend of women's employment in Britain in the last two decades is that women are increasingly employed in part-time jobs. In 1994, there were 4.7 million part-time women employees, but only 700,000 part-time male workers. There has been a fall in the proportion of full-time workers since 1970, to be set against increases in the proportions of self-employed, and part-time workers: while the proportion of full-time women employees fell by 3.8 percent between 1979 and 1993, there was a 3.4 percent increase in the proportion of women part-timers, and only a 0.4 percent increase in the proportion of self-employed women. However, a significant decrease of 9.3 percent in the proportion of men full-time workers was matched by a 6.3

${ }^{54}$ L. Hunter and S. Rimmer, 'An Economic Exploration of the U.K. and Australian Experiences', in J. Humpries and J. Rubery (eds.), The Economics of Equal Opportunities, Manchester, Equal Opportunities Commission, 1985, p.252.

${ }^{55}$ EOC (Equal Opportunities Commission), Some Facts About Women 1994, Manchester, EOC Press, 1995.

${ }^{56}$ D. Perrons and J. Shaw (eds.), 'Recent Changes in Women's Employment in Britain', in Making Gender Work: Managing Equal Opportunities, Buckingham, Open University Press, 1995, p.19.

${ }^{57}$ M. F. Özbilgin, 'Is The Practice of Equal Opportunities Management Keeping Pace With Theory?: Management of Sex Equality in the Financial Services Sector in Britain and Turkey', Human Resource Development International, Vol. 3 (1), 2000, pp. 43-67.

58 EOC, Some Facts About Women, 1994. 
percent increase in the proportion of self-employed men, and an increase of only 2.9 percent in the proportion of part-time male workers. ${ }^{59}$ These changes in the composition of employment suggest the feminisation of part-time employment. As Crompton and Sanderson point out: 60

In Britain... part-timers who work less than sixteen hours a week are not covered by the Employment Protection Act, and part-timers are often not eligible for bonus schemes, pension benefits, or holiday pay.

Thus, the lower status and benefits that part-time employees enjoy compared to their full-time and self-employed counterparts constituted an issue of sex equality, as it affected women more than men. ${ }^{61}$ Britain has the second highest rate of part-time female employment in European Union after the Netherlands. ${ }^{62}$ This is due to both the lack of adequate child-care provision, and also the economic advantages of such employment for British employers. In Turkey, parttime employment is controlled by the same legal measures as full-time employment, providing part-time workers with the same employment, pension, and unionisation rights, and holiday and sick pay entitlements as full-time workers. Thus, part-time work is unattractive economically for Turkish employers, whereas it is for British employers, due to the lower statutory benefits associated with part-time employment. Therefore, part-time employment in Turkey has been largely confined to domestic services such as cleaning, and also workers with high-level technical expertise, such as doctors, lawyers, engineers, and tax consultants, in small-scale organisations. ${ }^{63}$ This comparison between Britain and Turkey suggests that the increase in women's participation

${ }^{59}$ R. Gregg and J. Wadsworth, 'Gender Households and Access to Employment', in Humphries and Rubery (eds.), The Economics of Equal Opportunities.

${ }^{60} \mathrm{R}$. Crompton and K. Sanderson, 'The Gendered Restructuring of Work in The Finance Sector' in A. M. Scott (ed.), Gender, Segregation and Social Change, Oxford, Oxford University Press, 1994, p. 60.

${ }^{61}$ L. Blackwell 'Occupational Sex Segregation and Part-time Work in Modern Britain', Gender Work and Organization, Vol. 8 (2), pp. 146-163.

${ }^{62}$ European Industrial Relations Observatory (EIRO), Annual Review 2000, A Review of the Developments in European Industrial Relations, Luxembourg, EIRO, 2001, p. 33.

${ }^{63}$ N. Çelik, İs Hukuku Dersleri, İstanbul, 1988, pp. 52-53. 
in part-time work is largely due to employers' intentions to exploit labour market opportunities.

Lastly, women still receive lower wages than men in Britain. There was a gradual change in women's full-time hourly earnings as a percentage of men's since 1975. Although there is a modest 10 percent change towards equality over the last two decades, women are persistently paid lower wages than men, e.g. 81 percent in 1999.64 Thus, in Britain, despite a history of equal opportunities legislation since the 1970s, statistical indicators suggest that women in employment still constitute an underrepresented, underpaid, and disadvantaged group.

Evaluating the past, and future trends of equal opportunities in Britain, Storey identified two distinct approaches to management of sex equality, and names them as 'regulation' versus 'persuasion' approaches: ${ }^{65}$

During the 1980s and early 1990s, the idea of increased state regulation in this arena seemed implausible, and indeed the very existence of the EOC came under scrutiny. The main thrust in equal opportunities during that period rested increasingly on the notion of 'the business case', and this was allied with the equally popular idea of managing, and exploiting the 'diversity'. With so much emphasis on the voluntary, and enlightened self-interested path to 'equality of opportunity', the social justice case based on the notion of fairness was similarly masked, and to an extent even suppressed. In the climate fostered by a change of government in 1997, these relatively neglected rationales, and strategies have been resurrected.

A relatively new approach, which emerged from the North American school of 'diversity management', argues that equal opportunities initiatives can only be successful if they contribute to the strategic success of the industry. This 'industry-driven' approach is also referred to as the 'business case' for sex equality. There is

\footnotetext{
${ }^{64}$ Equal Opportunities Commission, Some Facts About Women 2000, Manchester, EOC Press, 2001.

${ }^{65} \mathrm{~J}$. Storey, 'Equal Opportunities in Retrospect and Prospect', Human Resource Management Journal, Vol. 9(1), pp. 5-6.
} 
evidence of increased recognition of this approach by British companies. Liff ${ }^{66}$ argued that the 'legislation-led' approaches to sex equality were only partially successful, and the 'industry-led' approaches did not deliver the cultural change that they promised. However, it is important to recognise that when combined, legislative and strategic business cases for equality may have a greater impetus for real sex equality in Britain.

\section{Implications For Management}

Studying development of sex equality in employment from a cross-national and comparative perspective poses a challenge to ethnocentric understandings of gendered forms of employment discrimination, and promises a means to understand the effectiveness of strategies and techniques assume to promote sex equality. Studying Turkey and Britain in this context is very important as they represent the margins of the European cultural geography and sex equality practice, and comparative analysis of their experiences is educational for both practitioners and academics in the field.

\section{Comparison and Discussions}

Commonalties between Turkey and Britain in terms of discourses and practices of sex equality are striking, particularly if we consider that these two countries hold different economic and political histories. This paper reveals that despite geographical, historical, economic, and cultural differences between the two countries, women in both countries share a common position as disadvantaged groups in employment. The statistical indicators of discrimination in employment, and gender gap in pay, and examination of legislative provision and institutional support for equality of opportunity in employment in both countries suggest that there is still ample opportunity for progress towards sex equality. The European Union, and CEDAW provide international push for legal and structural change in Turkey and Britain. At the national level, there are efforts to

${ }^{66}$ S. Liff, 'Diversity and Equal Opportunities: Room for a Constructive Compromise', Human Resource Management Journal, Vol. 9 (1), pp. 65-75. 
improve legal frameworks and national agencies of equality. Although there are push factors at national and international levels for both governments to implement effective strategies of sex equality, the pace of change towards equality so far has been slow in both countries.

However, these similarities between Turkey and Britain should not be overstated as differences and current divergence between their national agendas of change and practices of sex equality are more interesting to study. They are interesting, because the experiences of both countries reveal that gender relations are both outcomes and catalysts of their divergent macro economic and social issues. ${ }^{67}$ In the case of Turkey, gender relations are not mainstreamed, and thus sex equality issues did not inform the processes of urbanisation, economic, and political change. In Britain, however, sex equality discourse is mainstreamed at the level of national policy making since the 1997 elections.

Policy making at the state level is considered significant in providing, promoting, and protecting the equal rights of women at work in both countries. However, the nature of this support is different in Britain and Turkey. The traditional forms of state support have been losing their national significance for a number of years in Turkey. Since the late 1980s, growing concerns over Turkey's fragile macro economic performance meant that issues of sex equality issues are marginalized at state level policy making. For example, women's inclusion in the labour market is no longer considered a significant aspect of the 80-year-old national modernisation project. Liberalisation of the Turkish economy coupled with withdrawal of state support for equality, and negative impacts of migration, recession, and political turbulence have lead to a continued decrease in women's economic activity rates. However, as part of Turkey's bid to join the European Union, there is a growing awareness of the urgency for making adjustments to bring Turkish legislation in line with European Union legislative frameworks. One of these will be a legal framework for protection against sex discrimination in employment. In Britain, however, the proportion of women in the labour market has been

${ }^{67}$ M. F. Özbilgin, A Cross Cultural Comparative Analysis of Sex Equality in Financial Services Sector in Turkey and Britain, Unpublished $\mathrm{PhD}$. Thesis, University of Bristol, 1998. 
consistently increasing, and a protective legal framework, which Turkey is recommended to have, has been available since the 1970s. However, the legal push for equality in Britain has failed to deliver the expected outcomes of social and cultural change towards sex equality. After 30 years of equal opportunities legislation, vertical and horizontal sex segregation, and gender gap in pay are still intact in Britain. It can be argued that this was partly due to the failure of the legal system to attract ideological support from the British industry. Therefore, recognising the scant evidence of success in legal change, this paper highlights the importance of legal as well as institutional support for equality issues. This will require creative formulations of the partnership of industry and the state in eliminating sex discrimination.

\section{Directions for Future Research}

There is a level of legal and institutional support for women in employment in Turkey and Britain, carried out by civil organisations, sex equality initiatives of the industry, workers' unions, and the designated state institutions of equality (e.g. the Directorate General of Women's Status and Problems in Turkey, and the Equal Opportunities Commission in Britain). However, both countries require further structural reforms in their national mechanisms of sex equality. The evidence from Britain suggest that the proliferation of national agencies of sex, race, and disability deems equal opportunities issues at the cross section of these social classifications unduly complex. There are also concerns over uneven distribution of already limited funds between these institutions. Therefore, an umbrella organisation may be established in order to address diverse equality needs of women from different social and economic backgrounds. Turkey also needs structural reforms in the role of its national mechanism. If the Directorate General of Status and Problems of Women is to make a real impact, it should be adequately funded and empowered with rights to represent individual complaints in courts, and declare opinion on, and contribute to national planning efforts. These changes, however, are unlikely under the current economic crisis, and without financial assistance from the European Union, in order for Turkey to meet the Copenhagen criteria. 
It is possible to identify two distinctively different approaches to elimination of sex discrimination in these two countries. These could be named as 'the legislation-driven', and 'the industry-driven' approaches. Britain has been advocating the legal and moral case for equality for some time now, and equal opportunities in Turkey has been aligned to the national modernisation project since the early 1920s. However, Turkey is likely to adopt a 'legislation-driven' approach in the near future. The policy making efforts in the Turkish industry appear to be preoccupied by mainstream/male stream economic priorities, failing to recognise relevance of sex equality in a time of economic recession. In order for Turkish government to place equality issues in the operational and strategic mechanisms of the industry, adopting the European Union acquits in sex equality maybe a solution. However, the British experience indicates that legislation driven approaches to sex equality are not enough on their own in promoting real change towards sex equality. It is evident in the literature that the 'legislation-driven' and 'industry-driven' approaches are theorised as if they are in a binary opposition. This paper argues that such polarised applications of sex equality in Britain and Turkey have failed to deliver the desired results. Considering these approaches as irreconcilable poles of equal opportunities practice considerably diminishes their chances of success. Therefore, this paper suggests that, rather than adopting an 'either-or' approach between 'the legislation-driven', and 'the industrydriven' approaches to sex equality, a contingency approach, which recognises the uses and limitations of these approaches, and combines them effectively, could be more instrumental in promoting 'real' change towards sex equality. This study is a starting point for future research, and replication of the search in diverse context is essential. 


\section{Annex: Sex Equality Issues in Turkey and Britain}

\begin{tabular}{|c|c|c|}
\hline Sex Equality Issues & Turkey & Britain \\
\hline Common issues & \multicolumn{2}{|l|}{$\begin{array}{l}\text { Slow pace of change } \\
\text { Discrimination in employment } \\
\text { European Union as a driving force }\end{array}$} \\
\hline Major national issues & $\begin{array}{l}\text { Decreasing female labour participation } \\
\text { Gendered impact of migration, recession } \\
\text { and resurgence of religious right. } \\
\text { Continued sex segregation in employment } \\
\text { Disintegration of secularism and Kemalist } \\
\text { principles. } \\
\text { Inadequate state support for equality. } \\
\text { Increased need for legislation. }\end{array}$ & $\begin{array}{l}\text { Increasing female labour participation } \\
\text { Continued sex segregation in employment } \\
\text { Feminisation of part time work. } \\
\text { Glass ceiling, vertical and horizontal sex } \\
\text { segregation. } \\
\text { Discriminatory work cultures; long-hours, } \\
\text { man-only networking, and masculinism. } \\
\text { Inadequate state support. } \\
\text { Uneven impact of devolution. } \\
\text { High rates of teenager conception. }\end{array}$ \\
\hline Legal framework & $\begin{array}{l}\text { Rudimentary legislation } \\
\text { Turkish constitution states that men and } \\
\text { women are equal before the law. } \\
\text { There is no further equal opportunities } \\
\text { legislation. } \\
\text { CEDAW was ratified in } 1986 . \\
\text { Legal change is expected. }\end{array}$ & $\begin{array}{l}\text { Extensive liberal legislation } \\
\text { Sex Discrimination Act (1975) } \\
\text { Race Relations Act (1976) } \\
\text { Disability Discrimination Act (1995) } \\
\text { Sex Discrimination Act (as amended in } \\
\text { 1996), The Protection from Harassment Act } \\
\text { (1997), The Sex Offenders Act (1997), and } \\
\text { The National Minimum Wage Act (1999) } \\
\text { were instrumental in mainstreaming of } \\
\text { equality. } \\
\text { Human Rights Act (1998). } \\
\text { CEDAW (1986) } \\
\text { Britain is subject to European Union } \\
\text { legislation and case law. }\end{array}$ \\
\hline National machinery & $\begin{array}{l}\text { Directorate General of Women's Status and } \\
\text { Problems, est. } 1990 .\end{array}$ & Equal Opportunities Commission, est. 1976 \\
\hline $\begin{array}{l}\text { Organisational policy } \\
\text { approach }\end{array}$ & $\begin{array}{l}\text { Non-discrimination is assumed. } \\
\text { Anti-discriminatory action is voluntary } \\
\text { without penalty for non-compliance. } \\
\text { There are court cases awaiting ruling. }\end{array}$ & $\begin{array}{l}\text { Law requires non-discrimination. } \\
\text { There is penalty for discrimination by sex. } \\
\text { Positive discrimination is unlawful. }\end{array}$ \\
\hline $\begin{array}{l}\text { Main drivers for } \\
\text { change }\end{array}$ & $\begin{array}{l}\text { National modernisation project International } \\
\text { agreements } \\
\text { Feminist activism }\end{array}$ & $\begin{array}{l}\text { Feminist activism } \\
\text { EOC } \\
\text { Business and ethical cases } \\
\end{array}$ \\
\hline The way forward & $\begin{array}{l}\text { Structural change supporting the } \\
\text { implementation of the CEDAW and } \\
\text { broadening the scope of the DGWSP. } \\
\text { Legal change: introduction of laws on sex } \\
\text { equality. Introduction of public and private } \\
\text { partnership in tackling discrimination: } \\
\text { introduction of the business case for equality }\end{array}$ & $\begin{array}{l}\text { Umbrella institution to recognize diversity } \\
\text { in female population by sex, race etc. } \\
\text { Human Rights Commission. } \\
\text { National support for work-life balance may } \\
\text { encourage culture change. } \\
\text { Extending the mainstreaming of legislation } \\
\text { to the Northern Ireland. }\end{array}$ \\
\hline $\begin{array}{l}\text { Implications of cross- } \\
\text { national comparisons }\end{array}$ & \multicolumn{2}{|c|}{$\begin{array}{l}\text { Gender cultures and structures are not culturally or biologically predetermined. Their } \\
\text { development are constructed through social and economic experiences. Therefore, the } \\
\text { gender based inequalities in employment are not destiny and that they can be challenged } \\
\text { using a combination of eclectic strategies such as awareness raising, policy and law making } \\
\text { and political campaigning. }\end{array}$} \\
\hline
\end{tabular}

